\title{
THE EFFECT OF DIET ON BLOOD SUGAR IN DIABETES MELLITUS *
}

\author{
HERMAN O. MOSENTHAL, M.D., SAMUEL W. CLAUSEN, M.D. \\ AND \\ ALMA HILLER, M.D. \\ BALTIMORE
}

This investigation was undertaken partly on account of its physiologic interest and partly in the hope that it might yield information which would enable the clinician to interpret blood sugar values taken at any time of the day. The blood sugar was determined at hourly intervals in cases of diabetes mellitus. These patients were ordered diets which were adjusted to the therapeutic needs of the individual. That is, the diets were either "carbohydrate-free," containing no starch except that found in green vegetables, or, save for a very few instances, limited in starch content, so that the glycosuria was held in abeyance or at a low level. The results obtained under these circumstances, while they do not exhaust the subject from the physiologic or pathologic-physiologic point of view, are applicable to the practical interpretation of blood sugars in the treatment of diabetes mellitus. The method of Lewis and Benedict ${ }^{1}$ was employed to determine the blood sugar; Benedict's ${ }^{2}$ modification of Fehling's solution was used in estimating the sugar in the urine.

It is well known that the ingestion of glucose or a meal high in carbohydrate will increase the blood sugar in every human being, whether diabetic or not; however, normal individuals do not have a rise in their blood sugar after taking either protein or fat. This fact has been determined by Jacobsen, ${ }^{3}$ Strouse, ${ }^{4}$ and Rolly and Oppermann, ${ }^{5}$ and is substantiated in the present investigation. There is no evidence in a normal person of a hyperglycemia when the blood sugar is taken at frequent intervals after a single large carbohydrate-free meal (Table 1), nor if determined in hourly specimens throughout the course of the day when three such meals are given (Tables 2 and 3 ). These experiments may be considered as controls for the observations made on the cases of diabetes mellitus.

* Submitted for publication July 31, 1917.

* From the Medical Clinic of The Johns Hopkins Hospital.

1. Lewis and Benedict: Jour. Biol. Chem., 1915, 20, 61.

2. Benedict: Jour. Biol. Chem., 1911, 9, 57.

3. Jacobsen, A.: Biochem. Ztschr., 1913, 56, 471.

4. Strouse, S., Stein, I., and Wiseley, A.: Bull. Johns Hopkins Hosp., 1915, 26, 211 .

5. Rolly, F., and Oppermann: Biochem. Ztschr., 1913, 49, 278. 


\begin{tabular}{|c|c|c|c|c|c|}
\hline \multirow[b]{2}{*}{ Time } & \multirow{2}{*}{$\begin{array}{c}\text { Blood } \\
\text { Sugar, } \\
\text { per Cent. }\end{array}$} & \multicolumn{4}{|c|}{ Diet } \\
\hline & & Protein & Fat & $\begin{array}{l}\text { Carbo- } \\
\text { hyđrate }\end{array}$ & $\begin{array}{c}\text { Total } \\
\text { Calories }\end{array}$ \\
\hline 9:27 a.m. & $0.10^{*}$ & & & & \\
\hline $10: 00$ to $10: 20$ & $\cdots$ & 67 & 59 & 4 & 840 \\
\hline $10: 31$ & 0.10 & & & & \\
\hline $10: 51$ & 0.30 & & & & \\
\hline 11:10 & 0.09 & & & & \\
\hline 11:36 & 0.10 & & & & \\
\hline 12:16 p.m. & 0.10 & & & & \\
\hline $12: 48$ & 0.10 & & & & \\
\hline $1: 57$ & 0.10 & · & & & \\
\hline $2: 53$ & 0.12 & & & & \\
\hline
\end{tabular}

Table 1.-Blood sugar determinations at frequent intervals in a normal individual after a large carbohydrate-free meal. There is no evidence of any increase in the glycemia.

* Fasting.

\begin{tabular}{|c|c|c|c|c|c|}
\hline \multirow[b]{2}{*}{ Time } & \multirow{2}{*}{$\begin{array}{c}\text { Blood } \\
\text { Sugar, } \\
\text { per Cent. }\end{array}$} & \multicolumn{4}{|c|}{ Diet } \\
\hline & & Protein & Fat & $\begin{array}{l}\text { Carbo- } \\
\text { hydrate }\end{array}$ & $\begin{array}{c}\text { Total } \\
\text { Calories }\end{array}$ \\
\hline $9: 05$ a.m. & $0.12^{*}$ & & & & \\
\hline $9: 35$ to $9: 50$ & $\ldots$ & 30 & 42 & 3 & 526 \\
\hline $10: 33$ & 0.12 & & & & \\
\hline $11: 38$ & 0.12 & & & & \\
\hline $12: 20$ to $12: 35$ p.m. & $\ldots$ & 34 & 13 & 3 & 273 \\
\hline $1: 06$ & 0.12 & & & & \\
\hline $2: 09$ & 0.12 & & & & \\
\hline $3: 09$ & 0.09 & & & & \\
\hline $4: 10$ & 0.12 & & & & \\
\hline $5: 00$ to $5: 20$ & $\ldots$ & 30 & 45 & 0 & 960 \\
\hline $6: 20$ & 0.12 & & & & \\
\hline $8: 30$ & 0.12 & & & & \\
\hline
\end{tabular}

Table 2.-Blood sugar determinations at hourly intervals in a normal individual on a carbohydrate-free diet. There is no evidence of any change in the level of blood sugar throughout the day.

- Fasting. 


\begin{tabular}{|c|c|c|c|c|c|}
\hline \multirow[b]{2}{*}{ T'ime } & \multirow{2}{*}{$\begin{array}{c}\text { Blood } \\
\text { Sugar, } \\
\text { per Cent. }\end{array}$} & \multicolumn{4}{|c|}{ Diet } \\
\hline & & Proteln & F at & $\begin{array}{l}\text { Carbo- } \\
\text { bydrate }\end{array}$ & $\begin{array}{c}\text { Total } \\
\text { Calories }\end{array}$ \\
\hline 9:12 a.m. & $0.12^{*}$ & & & 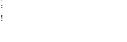 & \\
\hline $9: 30$ to $9: 45$ & $\ldots$ & 30 & 42 & 3 & 526 \\
\hline $10: 37$ & 0.12 & & & & \\
\hline 11:41 & 0.12 & & & & \\
\hline 12:20 to $12: 35$ p.m. & $\ldots$ & 25 & 10 & 10 & 237 \\
\hline $1: 08$ & 0.12 & & & ! & \\
\hline $2: 10$ & 0.12 & & & 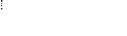 & \\
\hline $3: 12$ & 0.10 & & & 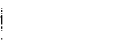 & \\
\hline $4: 13$ & 0.12 & & & & \\
\hline $5: 05$ to $5: 14$ & $\ldots$ & 45 & 51 & 10 & 700 \\
\hline $6: 25$ & 0.12 & & & & \\
\hline $8: 30$ & 0.12 & & & & \\
\hline
\end{tabular}

Table 3.-Blood sugar determinations at hourly intervals in a normal individual on a carbohydrate-free diet. There is no evidence of any change in the level of blood sugar throughout the day.

* Fasting.

\begin{tabular}{|c|c|c|c|c|c|c|c|}
\hline \multirow[b]{2}{*}{ Time } & \multirow{2}{*}{$\begin{array}{c}\text { ' } \\
\text { Blood } \\
\text { pugar, Cent. }\end{array}$} & \multicolumn{4}{|c|}{ Diet } & \multicolumn{2}{|c|}{ Urine Glucose, Gm. } \\
\hline & & Protein & Fat & $\begin{array}{l}\text { Carbo- } \\
\text { hydrate }\end{array}$ & $\begin{array}{c}\text { Total } \\
\text { Calories }\end{array}$ & $\begin{array}{c}\text { For } \\
\text { Period }\end{array}$ & $\begin{array}{c}\text { Per } \\
\text { Hour }\end{array}$ \\
\hline 8:15 a.m. & $0.16^{*}$ & & & & & & \\
\hline $9: 25$ to $9: 34$ & $\ldots$ & 19 & 34 & 45 & 578 & & \\
\hline $6: 00$ to $10: 35$ & $\ldots$ & .. & .. & $\ldots$ & $\ldots$ & 3.02 & 0.66 \\
\hline $10: 52$ & 0.23 & & & & & & \\
\hline 11:50 & 6.23 & & & & & & \\
\hline $11: 53$ to $12: 17$ p.m. & $\cdots$ & 60 & 26 & 116 & 863 & & \\
\hline $12: 30$ & $\ldots$. & .. & .. & $\ldots$ & ... & 3.00 & 1.82 \\
\hline $1: 20$ & 0.23 & & & & & & \\
\hline $2: 23$ & 0.26 & & & & & & \\
\hline $2: 25$ & $\ldots$ & .. & .. & $\ldots$ & ... & 6.81 & 8.55 \\
\hline $8: 25$ & 0.26 & & & & & & \\
\hline $3: 27$ & $\cdots$ & $\cdots$ & .. & $\cdots$ & $\ldots$ & 6.71 & 6.48 \\
\hline $4: 42$ & 0.26 & & & & & & \\
\hline $4: 45$ & $\ldots$ & .. & .. & $\ldots$ & $\ldots$ & 5.23 & 4.02 \\
\hline $5: 18$ to $5: 34$ & $\cdots$ & 24 & 50 & 75 & 871 & & \\
\hline $6: 30$ & 0.26 & .. & .. & $\cdots$ & $\ldots$ & 5.78 & 3.31 \\
\hline $7: 50$ & 0.32 & & & & & & \\
\hline 6:00 a.m. & $\ldots$ & .. & $\cdots$ & $\cdots$ & $\cdots$ & 40.32 & 8.51 \\
\hline $9: 00$ & $0.21^{*}$ & & & & & & \\
\hline
\end{tabular}

Table 4.-Blood sugar determinations at hourly intervals in a case of diabetes mellitus on a diet containing considerable starch. The level of blood sugar rises successively after each meal. There is a large quantity of sugar in the urine.

* Fasting. 


\begin{tabular}{c|c|c|c|c|c}
\hline \hline Time & $\begin{array}{c}\text { Blond } \\
\text { Sugar, } \\
\text { per Cent. }\end{array}$ & Protein & Fat & $\begin{array}{c}\text { Carbo- } \\
\text { hydrate }\end{array}$ & $\begin{array}{c}\text { Total } \\
\text { Calories }\end{array}$ \\
\hline $9: 24$ a.m. & $0.15^{*}$ & & & & \\
$9: 50$ to $10: 20$ & $\ldots$. & 77 & 79 & & \\
$10: 28$ & 0.15 & & & \\
$10: 47$ & 0.15 & & & \\
$11: 08$ & 0.18 & & & \\
$11: 34$ & 0.18 & & & \\
$12: 13$ p.m. & 0.18 & & & \\
$12: 47$ & 0.15 & & & \\
$1: 53$ & 0.15 & & & \\
$2: 51$ & 0.15 & & & \\
$4: 24$ & 0.15 & & & \\
\hline
\end{tabular}

Table 5.-Blood sugar determinations at frequent intervals in a case of diabetes mellitus after a large carbohydrate-free meal. There is a distinct rise of blood sugar forty-eight minutes after the meal is taken. This hyperglycemia is maintained at least one hour and five minutes.

- Fasting.

\begin{tabular}{|c|c|c|c|c|c|}
\hline \multirow[b]{2}{*}{ Time } & \multirow{2}{*}{$\begin{array}{c}\text { Blood } \\
\text { Sugar, } \\
\text { per Cent. }\end{array}$} & \multicolumn{4}{|c|}{ Diet } \\
\hline & & Protein & Fat & $\begin{array}{l}\text { Oarbo- } \\
\text { hydrate }\end{array}$ & $\begin{array}{l}\text { Total } \\
\text { Calories }\end{array}$ \\
\hline 11:04 a.m. & $0.18^{*}$ & & & & \\
\hline 11:35 a.m. to $12: 05$ p.m. & $\ldots$ & 77 & 79 & 14 & 1,108 \\
\hline 12:19 & 0.18 & & & & \\
\hline $12: 51$ & 0.23 & & & & \\
\hline $1: 24$ & 0.28 & & & & \\
\hline $2: 38$ & 0.19 & & & & \\
\hline $3: 35$ & 0.16 & & & & \\
\hline $4: 46$ & 0.78 & & & & \\
\hline
\end{tabular}

Table 6.-Blood sugar determinations at frequent intervals in a case of diabetes mellitus after a large carbohydrate-free meal. There is a distinct rise of blood sugar forty-six minutes after the meal is taken. This hyperglycemia is maintained at least thirty-three minutes.

* Fasting.

In interpreting blood sugars obtained in diabetic individuals the clinician often takes for granted that every meal will result in an increase in the glycemia, so that the glucose in the blood will reach its maximum by steplike gradations in the evening. This conclusion, thus far, rests on what seems to be obvious reasoning, but not on 


\begin{tabular}{|c|c|c|c|c|c|}
\hline \multirow[b]{2}{*}{ Time } & \multirow{2}{*}{$\begin{array}{c}\text { Blood } \\
\text { Sugar, } \\
\text { per Cent. }\end{array}$} & \multicolumn{4}{|c|}{ Diet } \\
\hline & & Protein & F at & $\begin{array}{c}\text { Carbo- } \\
\text { hydrate }\end{array}$ & $\begin{array}{c}\text { Total } \\
\text { Calories }\end{array}$ \\
\hline 9:35 a.m. & $0.07^{*}$ & & & & \\
\hline $9: 55$ to $10: 20$ & $\cdots$ & 77 & 79 & 14 & 1,108 \\
\hline $10: 85$ & 0.07 & & & & \\
\hline $10: 52$ & $0.0 \%$ & & & & \\
\hline 11:10 & 0.09 & & & & \\
\hline $11: 35$ & 009 & & & & \\
\hline 12:22 p.m. & 0.09 & & & & \\
\hline $1: 25$ & 0.11 & & & & \\
\hline $2: 20$ & 0.11 & & & & \\
\hline
\end{tabular}

Table 7.-Blood sugar determinations at frequent intervals in a case of very mild diabetes mellitus after a large carbohydrate-free meal. There is a slight rise of blood sugar at the end of fifty minutes. This not only persists, but increases during the next three hours and ten minutes, when the observation is terminated.

* Fasting.

\begin{tabular}{c|c|c|c|c|c}
\hline & & \multicolumn{4}{|c|}{ Diet } \\
\hline Time & $\begin{array}{c}\text { Blood } \\
\text { Sugar } \\
\text { per Cent. }\end{array}$ & Protein & Fat & $\begin{array}{c}\text { Oarbo- } \\
\text { hydrate }\end{array}$ & $\begin{array}{c}\text { Total } \\
\text { Calories }\end{array}$ \\
\hline 9:15 a.m. & $0.11^{*}$ & & & & \\
9:35 to 10:10 & $\ldots$ & 77 & 79 & 14 & 1,108 \\
10:15 & 0.13 & & & & \\
10:36 & 0.10 & & & & \\
10:52 & 0.11 & & & & \\
11:13 & 0.10 & & & & \\
11:44 & 0.11 & & & & \\
12:22 p.m. & 0.11 & & & & \\
1:25 & 0.11 & & & & \\
3:06 & 0.10 & & & & \\
4:10 & 0.10 & & & & \\
\hline
\end{tabular}

Table 8.-Blood sugar determinations at frequent intervals in a case of diabetes mellitus after a large carbohydrate-free meal. There is a slight, very transient, rise of blood sugar immediately following the intake of food. Hourly determinations of blood sugar would have missed this glycemia.

- Fasting. 


\begin{tabular}{|c|c|c|c|c|c|c|}
\hline \multirow[b]{2}{*}{ Time } & \multirow{2}{*}{$\begin{array}{c}\text { Blood } \\
\text { Sugar, } \\
\text { per Cent. }\end{array}$} & \multicolumn{4}{|c|}{ Diet } & \multirow[b]{2}{*}{ Urine } \\
\hline & & Protein & Fat & $\begin{array}{l}\text { Carbo- } \\
\text { hydrate }\end{array}$ & $\begin{array}{c}\text { Total } \\
\text { Calories }\end{array}$ & \\
\hline $8: 50$ a.m. & $0.18^{*}$ & .. & .. & . & $\ldots$ & $\begin{array}{l}\text { Contains no sugar } \\
\text { on this day }\end{array}$ \\
\hline 9:00 & $\ldots$. & 20 & 32 & 0 & 380 & \\
\hline $10: 00$ & 0.17 & & & & & \\
\hline 11:00 & 0.18 & & & & & \\
\hline 12:00 m. & 0.17 & & & & & \\
\hline 12:10 p.m. & $\ldots$ & 32 & 44 & 7 & 569 & . \\
\hline $1: 00$ & 0.17 & & & & & \\
\hline $2: 00$ & 0.17 & & & & & \\
\hline $3: 00$ & 0.17 & & & & & \\
\hline $4: 20$ & 0.13 & & & & & \\
\hline 5:00 & $\ldots$ & 24 & 24 & 6 & 346 & \\
\hline $6: 20$ & 0.17 & & & & & \\
\hline $8: 40$ & 0.11 & & & & & . \\
\hline $8: 50$ a.m. & $0.17^{*}$ & & & & & \\
\hline
\end{tabular}

Table 9.--Hourly blood sugar determinations in a case of diabetes mellitus while on a carbohydrate-free diet. There is no rise in the blood sugar above the fasting level. There is a tendency toward a diminished blood sugar in the afternoon and evening.

* Fasting.

experimental evidence. Under certain conditions it holds true. Thus, in Table 4 it is seen that the blood sugar rises after each meal, being 0.16 per cent., while fasting, 0.23 per cent. after breakfast, 0.26 per cent. after dinner, and 0.32 per cent. after supper. The fasting blood sugar determination of the next morning rises to 0.21 per cent., as compared to 0.16 per cent. of the previous day. This increase in the fasting blood sugar, as well as the marked glycosuria, indicates that the diet in this case is one which is most unsuitable to the needs of the patient. The blood sugar curve, with its steplike rise after each meal, obtained during the day, is one which may be considered typical of diabetes mellitus while the patient is receiving far more starchy food than is indicated. These, however, are not the conditions which ordinarily present themselves to the clinician, and to make a correct interpretation of blood sugar determinations made at various times of the day it is necessary to examine the results obtained in patients who are receiving the usual form of dietetic treatment. As is well known, the rise of blood sugar after the ingestion of glucose or starch is very much prolonged in the diabetic individual as compared to the normal. 


\begin{tabular}{|c|c|c|c|c|c|c|}
\hline \multirow[b]{2}{*}{ Time } & \multirow{2}{*}{$\begin{array}{c}\text { Blood } \\
\text { Sugar, } \\
\text { per Cent. }\end{array}$} & \multicolumn{4}{|c|}{ Diet } & \multirow[b]{2}{*}{ Urine } \\
\hline & & Protein & Fat & $\begin{array}{l}\text { Carbo- } \\
\text { hydrate }\end{array}$ & $\begin{array}{c}\text { Total } \\
\text { Calories }\end{array}$ & \\
\hline 8:55 a.m. & $0.45^{*}$ & $\cdots$ & .. & .. & $\cdots$ & Contains $5.5 \mathrm{gm}$. \\
\hline $9: 17$ to $9: 30$ & $\ldots$ & 20 & 32 & 0 & 380 & this day \\
\hline $10: 34$ & 0.45 & & & & & \\
\hline $11: 55$ & 0.45 & & & & & \\
\hline $12: 20$ to $12: 35$ p.m. & $\ldots$ & 36 & 14 & 6 & 302 & \\
\hline $1: 50$ & 0.45 & & & & & \\
\hline $2: 55$ & 0.45 & & . & & & \\
\hline $4: 00$ & 0.45 & & & & & \\
\hline $5: 00$ & 0.45 & & & & & \\
\hline $5: 10$ to $5: 15$ & $\ldots$ & 10 & 6 & 11 & 97 & \\
\hline $7: 05$ & 0.45 & & & & & \\
\hline $11: 35$ & $0.4 b$ & & & & & \\
\hline 8:30 a.m. & $0.45^{*}$ & & & & & \\
\hline
\end{tabular}

Table 10.- Hourly blood sugar determinations in a case of diabetes mellitus. Case complicated by an infected gangrenous process of one foot and by myocardial insufficiency. There is no change in the level of the blood sugar following the intake of a carbohydrate-free diet of rather low caloric value.

* Fasting.

\begin{tabular}{|c|c|c|c|c|c|c|}
\hline \multirow[b]{2}{*}{ Time } & \multirow{2}{*}{$\begin{array}{c}\text { Blood } \\
\text { Sugar, } \\
\text { per Cent. }\end{array}$} & \multicolumn{4}{|c|}{ Diet } & \multirow[b]{2}{*}{ Urine } \\
\hline & & Protein & Fat & $\begin{array}{l}\text { Carbo- } \\
\text { hydrate }\end{array}$ & $\begin{array}{c}\text { Total } \\
\text { Calories }\end{array}$ & \\
\hline s:30 a.m. & $0.23^{*}$ & . & .. & .. & $\ldots$ & $\begin{array}{l}\text { Contains no sugar } \\
\text { on this day }\end{array}$ \\
\hline $9: 00$ to $9: 15$ & $\ldots$. & 3) & 32 & 0 & 380 & \\
\hline $10: 00$ & 0.23 & & & & & \\
\hline $11: 45$ & 0.23 & & & & & \\
\hline 12:45 p.m. & 0.23 & & & & & \\
\hline $2: 00$ to $2: 20$ & $\ldots$. & 46 & 56 & 10 & 750 & \\
\hline $8: 20$ & 0.23 & & & & & \\
\hline $6: 00$ to $6: 25$ & $\ldots$. & 33 & 37 & 9 & 516 & \\
\hline $6: 46$ & 0.19 & & & & & \\
\hline $7: 20$ & 0.23 & & & & & \\
\hline $8: 30$ & 0.23 & & & & & \\
\hline 9:50 a.m. & $0.23^{*}$ & & & & & \\
\hline
\end{tabular}

Table 11.-Hourly blood sugar determinations in a case of diabetes mellitus while on a carbohydrate-free diet. There is no rise in the blood sugar above the fasting level as the result of food ingestion.

* Fasting. 


\begin{tabular}{|c|c|c|c|c|c|c|}
\hline \multirow[b]{2}{*}{ Time } & \multirow{2}{*}{$\begin{array}{c}\text { Blood } \\
\text { Sugai, } \\
\text { per Cent. }\end{array}$} & \multicolumn{4}{|c|}{ Diet } & \multirow[b]{2}{*}{ Urine } \\
\hline & & Protein & Fat & $\begin{array}{l}\text { Carbo- } \\
\text { hydrate }\end{array}$ & $\begin{array}{c}\text { 'Total } \\
\text { Oalories }\end{array}$ & \\
\hline 8:50 a.m. & $0.33^{*}$ & .. & .. & .. & $\ldots$ & Contains $50 \mathrm{gm}$. \\
\hline $9: 40$ to $9: 50$ & .... & 20 & 32 & 0 & 380 & this day \\
\hline $10: 50$ & 0.33 & & & & & \\
\hline $11: 50$ & 0.33 & & & & & \\
\hline $11: 5 \overline{5}$ to $12: 20$ p.m. & $\ldots$ & 23 & 65 & 7 & 728 & . \\
\hline $3: 00$ & 0.32 & & & & & \\
\hline $4: 05$ & 0.33 & & & & & \\
\hline $4: 50$ to $5: 00$ & $\ldots$ & 26 & 22 & 6 & 386 & \\
\hline $6: 35$ & 0.28 & & & & & \\
\hline
\end{tabular}

Table 12.-Hourly determinations of blood sugar in a case of diabetes mellitus while on a carbohydrate-free diet. The blood sugar throughout the day does not rise above the fasting level, although the initial blood sugar is high and there is a glycosuria.

* Fasting.

\begin{tabular}{|c|c|c|c|c|c|c|}
\hline \multirow[b]{2}{*}{ Time } & \multirow{2}{*}{$\begin{array}{c}\text { Blood } \\
\text { Sugar, } \\
\text { per Cent. }\end{array}$} & \multicolumn{4}{|c|}{ DHet } & \multirow[b]{2}{*}{ Orine } \\
\hline & & Protein & Fat & $\begin{array}{c}\text { Carbo- } \\
\text { hydrate }\end{array}$ & $\begin{array}{c}\text { Total } \\
\text { Calories }\end{array}$ & \\
\hline 8:11 a.m. & $0.18^{*}$ & .. & .. & .. & $\cdots$ & $\begin{array}{l}\text { Contains no sugar } \\
\text { on this day }\end{array}$ \\
\hline $8: 30$ to $8: 45$ & $\cdots$ & 30 & 36 & 0 & 458 & \\
\hline $9: 45$ & 0.18 & & & & & \\
\hline $11: 00$ & 0.18 & & & & & \\
\hline $11: 50$ & 0.18 & & & & & \\
\hline $12: 15$ to $12: 35$ p.m. & $\ldots$. & 47 & 54 & 19 & 773 & \\
\hline $1: 20$ & 0.18 & & & & & \\
\hline $2: 20$ & 0.19 & & & & & \\
\hline $3: 25$ & 0.18 & & & & & \\
\hline $4: 50$ to $5: 10$ & $\cdots \cdot$ & 50 & 53 & 7 & 727 & \\
\hline $6: 40$ & 0.18 & & & & & \\
\hline $8: 55$ & 0.18 & & & & & \\
\hline $8: 00$ a.m. & $0.18^{*}$ & & & & & \\
\hline
\end{tabular}

Table 13.-Hourly determinations of blood sugar in a case of diabetes mellitus while on a carbohydrate-free diet. The level of the blood sugar remains virtually constant throughout the day.

* Fasting. 


\begin{tabular}{|c|c|c|c|c|c|c|}
\hline \multirow[b]{2}{*}{ T'ime } & \multirow{2}{*}{$\begin{array}{c}\text { Blood } \\
\text { Sugar, } \\
\text { per Cent. }\end{array}$} & \multicolumn{4}{|c|}{ Diet } & \multirow[b]{2}{*}{ Urine } \\
\hline & & Protein & Fat & $\begin{array}{c}\text { Carbo- } \\
\text { hydrate }\end{array}$ & $\begin{array}{c}\text { Total } \\
\text { Calories }\end{array}$ & \\
\hline $8: 16$ a.m. & $0.17^{*}$ & . & . & .. & $\cdots$ & Cortains $30.6 \mathrm{gm}$. \\
\hline $9: 25$ to $0: 37$ & $\ldots$. & 30 & 42 & 3.0 & 526 & this day \\
\hline $10: 30$ & 0.17 & & & & & \\
\hline $11: 45$ & 0.17 & & & & & \\
\hline $11: 50$ to $12: 10 \mathrm{p.m}$. & $\ldots$ & 53 & 59 & 10.0 & 807 & \\
\hline $1: 10$ & 0.18 & & & & & \\
\hline $2: 90$ & 0.18 & & & & & \\
\hline $3: 20$ & 0.18 & & & & & \\
\hline $4: 20$ & 0.18 & & & & & \\
\hline $4: 50$ to $5: 10$ & $\ldots$ & 33 & 41 & 13.0 & 570 & \\
\hline $6: 35$ & 0.18 & & & & & \\
\hline $8: 30$ & 0.18 & & & & & \\
\hline 7:5̃ a.m. & $0.10^{*}$ & & & & & \\
\hline
\end{tabular}

Table 14.-Hourly blood sugar determinations in a case of diabetes mellitus while on a carbohydrate-free diet. Although the diet slightly exceeds the patient's carbohydrate tolerance, as shown by the sugar in the urine, the blood sugar level is scarcely raised throughout the day.

* Fasting.

This fact has been fully established by the findings of many observers. ${ }^{5}$ Recognizing the fact that the glycemia may rise as the result of food intake, and subsequently fall, it becomes necessary to ascertain whether the hourly determinations of blood sugar, as used in the present observations, are sufficiently frequent to detect any changes that are likely to occur after starch-free food. This question was determined by giving a diabetic individual a single large carbohydrate-free meal and estimating the blood sugar at frequent intervals. It has already been shown that in a normal person no hyperglycemia is demonstrable under these conditions (Table 1). In the diabetic, however, there may be a distinct, though often slight, rise in the blood sugar (Tables 5 to 8). When the percentage of glucose does rise it seems to remain at its maximum for a considerable period (Tables 5,6 and 7). It must be admitted that occasional slight transient rises of blood sugar occur after the taking of carbohydrate-free food, which would escape observation if the glycemia were determined at greater than fifteen-minute intervals (Table 8). Taking all the facts into consideration, however,

6. Tachau, H.: Deutsch. Arch. f. klin. Med., 1911, 104, 437. Jacobsen, A.: Biochem. Ztschr., 1913, 56, 471. Hopkins, A. H.: Am. Jour. Med. Sc., 1915, 149, 254. Hamman, L., and Hirschman, I.: To be published. 
it appears justifiable to conclude that blood sugar estimations made at approximately hourly intervals will reveal the more significant changes in the blood sugar level brought about by carbohydrate-free diets or meals low in starch, in cases of diabetes mellitus.

The examination of the results in cases in which the blood sugar was determined at hourly intervals throughout the day reveals the fact

\begin{tabular}{|c|c|c|c|c|c|c|}
\hline \multirow[b]{2}{*}{ Time } & \multirow{2}{*}{$\begin{array}{c}\text { Blood } \\
\text { Sugar, } \\
\text { per Cent. }\end{array}$} & \multicolumn{4}{|c|}{ Diet } & \multirow{2}{*}{$\begin{array}{l}\text { Urine } \\
\text { Glucose } \\
\text { Gm. per } \\
\text { Hour }\end{array}$} \\
\hline & & Protein & Fat & $\begin{array}{l}\text { Carbo- } \\
\text { hydrate }\end{array}$ & $\begin{array}{c}\text { Total } \\
\text { Calories }\end{array}$ & \\
\hline $7: 50$ a.m. & $0.12^{*}$ & & & & & \\
\hline $8: 00$ & $\ldots$ & .. & .. & .. & $\ldots$ & + \\
\hline $8: 18$ to $8: 22$ & $\ldots$ & 16 & 27 & 16 & 382 & \\
\hline $9: 00$ & $\ldots$. & .. & .. & . & $\cdots$ & 0.64 \\
\hline $9: 25$ & 0.19 & & & & & \\
\hline $10: 00$ & $\ldots$ & - & .. & .. & $\ldots$ & 1.10 \\
\hline $10: 80$ & 0.18 & & & & & \\
\hline $11: 00$ & $\ldots$. & .. & . & . & $\ldots$ & 1.12 \\
\hline $11: 30$ & 0.16 & & & & & \\
\hline 11:55 a.m. to $12: 10 \mathrm{p} . \mathrm{m}$. & $\ldots$ & 42 & 39 & 22 & 625 & \\
\hline $12: 00$ & $\cdots$ & .. & *. & .. & $\cdots$ & 1.81 \\
\hline $1: 00$ & $\cdots$ & .. & .. & .. & $\ldots$ & 1.89 \\
\hline $1: 10$ & 0.19 & & & & & \\
\hline $2: 00$ & $\ldots$. & .. & .. & .. & $\ldots$ & 1.28 \\
\hline 2:10 & 0.20 & & & & & \\
\hline $8: 10$ & .... & .. & . & . & $\cdots$ & 1.21 \\
\hline $8: 10$ & 0.18 & & & & & \\
\hline $4: 00$ & $\ldots$ & .. & .. & .. & $\ldots$ & 1.37 \\
\hline $4: 30$ & 0.16 & & & & & \\
\hline $5: 00$ & $\cdots$ & .. & . & . & $\cdots$ & 1.10 \\
\hline $5: 08$ to $5: 15$ & $\ldots$ & 89 & 28 & 22 & 492 & \\
\hline $6: 00$ & .... & .. & .. & .. & $\cdots$ & 0.50 \\
\hline $6: 80$ & 0.14 & & & & & \\
\hline $7: 00$ & .... & .. & .. & .. & $\ldots$ & 0.56 \\
\hline $8: 00$ & $\ldots$. & .. & .. & .. & $\cdots$ & 1.08 \\
\hline $8: 80^{\circ}$ & 0.16 & & & & & \\
\hline $\begin{array}{c}\text { 8:00 p.m. to } 6: 00 \text { a.m. } \\
\text { 7:40 a.m. }\end{array}$ & $0.14^{*}$ & .. & $\cdots$ & .. & $\ldots$ & Trace \\
\hline
\end{tabular}

Table 15.-Hourly determinations of blood sugar in a case of exophthalmic goiter and diabetes mellitus while on a diet containing a small amount of starch. There is a distinct rise of blood sugar after breakfast, which is slightly exceeded after the midday meal and diminishes after supper.

* Fasting. 


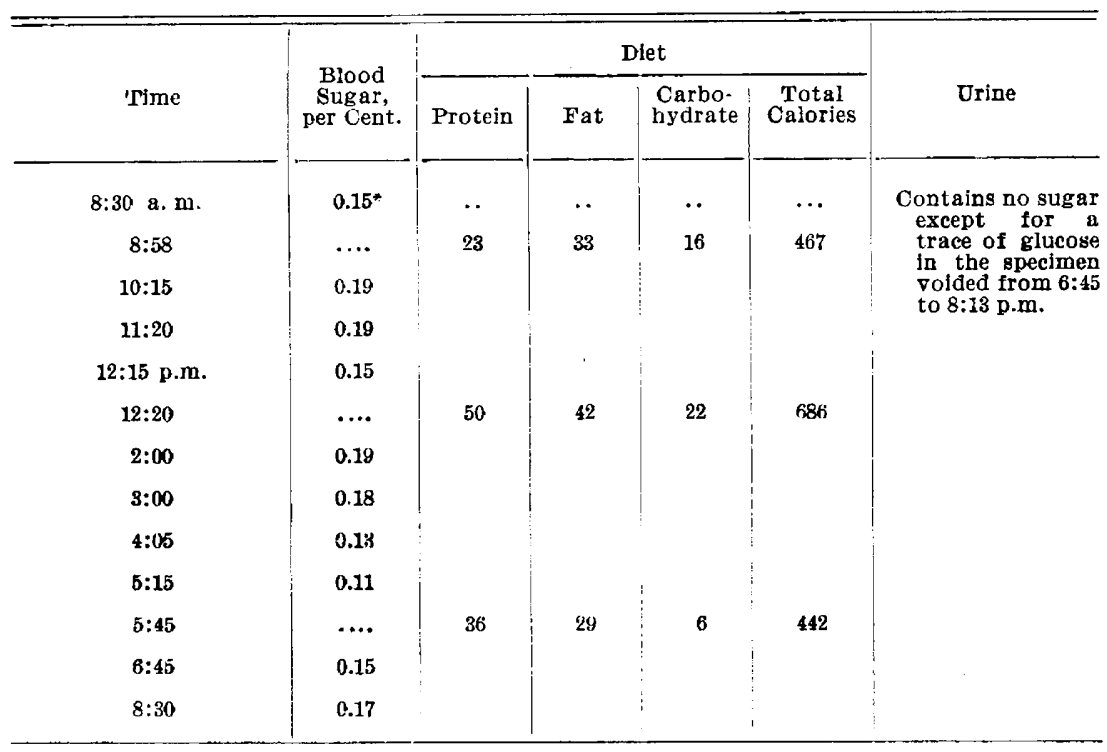

Table 16.- Hourly determinations of blood sugar in a case of exophthalmic goiter and diabetes mellitus. This observation was made after partial thyroidectomy, that of Table 15 before the operation. There is a distinct rise of blood sugar after breakfast, which is the maximum attained in the course of the day.

* Fasting.

that many of these exhibit no rise above the fasting level (Tables 9,10 , 11 and 12), or only a very slight increase of 0.01 per cent. (Tables 13 and 14), while others (Tables 15 to 20 , inclusive) give evidence of a considerable elevation in the blood sugar as the result of the intake of food.

It is readily seen that if the blood sugar rises at all, the most notable increase occurs within an hour or two after breakfast. There may in some instances be a further rise in the course of the day, but this is of comparatively small moment, since the initial increment after breakfast varies from 0.02 to 0.09 per cent., while the highest subsequent increase surpasses these by only 0.02 per cent. (Tables 15 to 20 , inclusive; also Table 21). Furthermore, it may be noted that, especially in the afternoon or evening hours, the blood sugar shows a tenciency to diminish. This is true when there is an increase after breakfast (Tables 15,16,18, 19 and 20), and also when this does not occur (Tables 9, 11 and 12). It may, therefore, be concluded that the maximal rise (or a rise approaching the maximal) of blood sugar occurs in diabetic patients on a carbohydrate-free diet, or one containing a moderate amount of starch, about one hour after breakfast. If it is the aim of the clinician to determine the maximal blood sugar per- 


\begin{tabular}{|c|c|c|c|c|c|c|}
\hline \multirow[b]{2}{*}{ Time } & \multirow{2}{*}{$\begin{array}{c}\text { Blood } \\
\text { Sugar, } \\
\text { per Cent. }\end{array}$} & \multicolumn{4}{|c|}{ Diet } & \multirow[b]{2}{*}{ Urine } \\
\hline & & Protein & Fat & $\begin{array}{l}\text { Carbo- } \\
\text { hydrate }\end{array}$ & $\begin{array}{c}\text { Total } \\
\text { Calories }\end{array}$ & \\
\hline 8:40 a.m. & $0.14^{*}$ & . & .. & ". & $\cdots$ & $\begin{array}{l}\text { Oontains no sugar } \\
\text { on this day }\end{array}$ \\
\hline $8: 45$ & $\cdots$ & 27 & 32 & 0 & 408 & \\
\hline $10: 00$ & 0.16 & & & & & \\
\hline 11:00 & 0.16 & & & & & \\
\hline i1: 50 & .... & 60 & 41 & 10 & 668 & \\
\hline 12:00 m. & 0.16 & & & & & \\
\hline 1:15 p.m. & 0.16 & & & & & \\
\hline $2: 15$ & 0.18 & & & & & \\
\hline$z: 27$ & 0.16 & & & & & \\
\hline $4: 30$ & 0.16 & & & & & \\
\hline $4: 35$ & $\cdots \cdot$ & 49 & 24 & 12 & 473 & \\
\hline $5: 55$ & 0.16 & & & & & \\
\hline $8: 00$ & 0.16 & & & & & \\
\hline 8:55 a.m. & $0.18^{*}$ & & & & & \\
\hline
\end{tabular}

Table 17.-Hourly blood sugar determinations in a case of diabetes mellitus while on a carbohydrate-free diet. The blood sugar rises after breakfast. This rise is exceeded only once during the day, after the noon meal.

* Fastlng.

\begin{tabular}{|c|c|c|c|c|c|c|}
\hline \multirow[b]{2}{*}{ Time } & \multirow{2}{*}{$\begin{array}{c}\text { Blood } \\
\text { Sugar, } \\
\text { per Cent. }\end{array}$} & \multicolumn{4}{|c|}{ Diet } & \multirow[b]{2}{*}{ Urine } \\
\hline & & Protein & Fat & $\begin{array}{l}\text { Carbo- } \\
\text { hydrate }\end{array}$ & $\begin{array}{c}\text { Total } \\
\text { Oalories }\end{array}$ & \\
\hline $8: 20$ a.m. & $0.13^{*}$ & .. & .. & .. & ... & Contains $12 \mathrm{gm}$. \\
\hline $8: 00$ to $9: 15$ & $\ldots$. & 29 & 42 & 0 & 510 & $\begin{array}{l}\text { of giucose o } \\
\text { this day }\end{array}$ \\
\hline $10: 10$ & 0.16 & & & & & \\
\hline $11: 30$ & 0.14 & & & & & \\
\hline 12:30 p.m. & (0.13 & & & & & \\
\hline $12: 30$ to $12: 45$ & $\cdots$ & 44 & 71 & 7 & 869 & \\
\hline $1: 55$ & 0.14 & & & & & \\
\hline$n: 00$ & 0.12 & & & & & \\
\hline $4: 00$ & 0.08 & & & & & \\
\hline $5: 15$ to $5: 30$ & $\cdots$ & 25 & 27 & 5 & 374 & \\
\hline $6: 45$ & 0.15 & & & & & \\
\hline $8: 45$ & 0.18 & & & & & \\
\hline 8:35 a.m. & $0.15^{*}$ & & & & & \\
\hline
\end{tabular}

Table 18.-Hourly blood sugar determinations in a case of diabetes mellitus while on a carbohydrate-free diet. The blood sugar in this patient rises slightly higher after the last meal of the day than after breakfast.

- Fasting. 
centage occurring in any individual, this is probably the most favorable time to obtain it, since in the afternoon and evening hours the blood sugar percentage has a distinct tendency to diminish, and thus may lead to an erroneous interpretation.

From the point of view of pathologic physiology, some interesting conclusions may be drawn from these observations. It is perfectly clear that in these cases which are being treated by a diet restricted in carbohydrates, each successive meal does not produce an increment of

\begin{tabular}{|c|c|c|c|c|c|c|}
\hline \multirow[b]{2}{*}{ Time } & \multirow{2}{*}{$\begin{array}{c}\text { Blood } \\
\text { Sugar, } \\
\text { per Cent. }\end{array}$} & \multicolumn{4}{|c|}{ Dlet } & \multirow[b]{2}{*}{ Urine } \\
\hline & & Protein & Fat & $\begin{array}{l}\text { Carbo- } \\
\text { hydrate }\end{array}$ & $\begin{array}{c}\text { Total } \\
\text { Calories }\end{array}$ & \\
\hline 9:15 a.m. & $0.16^{*}$ & .. & .. & .. & $\ldots$ & Contains $4 \mathrm{gm}$. of \\
\hline $9: 30$ & $\ldots$ & 21 & 13 & 58 & 445 & 24-hour specimen \\
\hline $10: 35$ & 0.25 & & & & & \\
\hline $11: 30$ & 0.23 & 20 & 20 & 73 & 567 & \\
\hline $12: 45 \mathrm{p} . \mathrm{m}$ & 0.23 & & & & & \\
\hline $1: 55$ & 0.23 & & & & & \\
\hline $3: 05$ & 0.22 & & & & & \\
\hline $4: 00$ & $\ldots$ & 7 & 8 & 17 & 173 & \\
\hline $4: 20$ & 0.22 & & & ( & & \\
\hline $5: 00$ & $\ldots$. & 19 & 17 & 40 & 400 & \\
\hline $5: 40$ & 0.22 & & & & & \\
\hline $6: 50$ & 0.26 & & & & & \\
\hline $8: 10$ & 0.23 & & & & & . \\
\hline $9: 05$ a.m & $0.15^{*}$ & & & & & \\
\hline
\end{tabular}

Table 19.- Hourly blood sugar determinations in a case of diabetes mellitus. Patient on a diet containing a moderate amount of starch, a little above the patient's carbohydrate tolerance. There is a marked rise of blood sugar after breakfast, which is surpassed by only a very slight margin at $6: 50 \mathrm{p} . \mathrm{m}$.

* Fasting.

blood sugar. This is contrary to the usual conception of the course of events, and the picture presented is quite different from that found in patients indulging in a high carbohydrate diet (Table 4). Hamman and Hirschman ${ }^{7}$ have demonstrated that superimposed doses of glucose are not necessarily followed by a steplike rise in the blood sugar. It is only the first dose that causes the blood sugar percentage to rise; the subsequent ones apparently have no effect. This substantiates the present findings.

7. Hamman, L., and Hirschman, I. I.: Studies on Blood Sugar, The ARchives INT. MED., 20, 761. 
A hypothesis suggests itself which may explain these phenomena. In Table 21, which summarizes the cases studied, it may be noted that the blood sugar values remain at the fasting level or below it throughout the day in those cases in which the initial hyperglycemia is marked ( 0.17 to 0.45 per cent., Tables 9 to 14$)$; whereas, it rises in those in which it is low ( 0.12 to 0.16 per cent., Tables 15 to 20 ). It seems that each diabetic has a blood sugar level at which his carbohydrate metabolism proceeds in a fairly normal manner, with no rise in the blood sugar after meals of a moderate starch content. In very mild cases this acquired blood sugar level may be very low and no increase result after eating a starch-free meal; whereas, in individuals with a very marked derangement in their carbohydrate metabolism, such a favor-

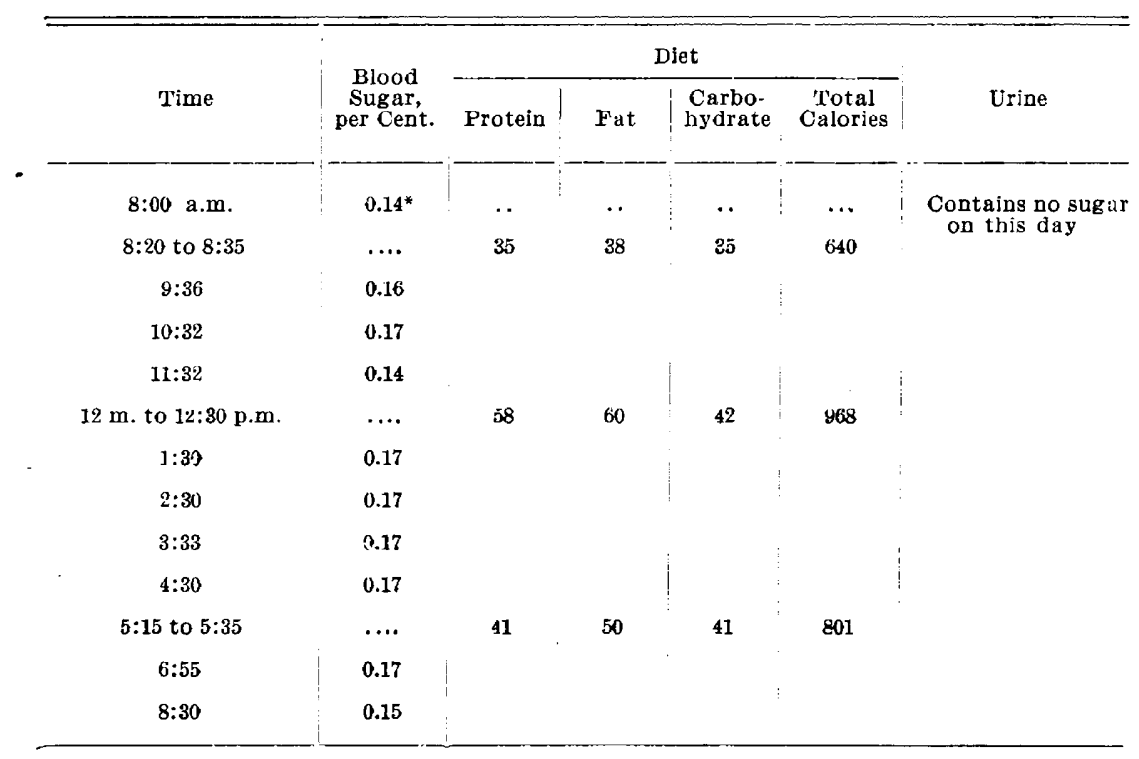

Table 20.-Hourly determinations of blood sugar in a case of diabetes mellitus. Patient on a diet containing a moderate amount of starch. There is a rise of the percentage of blood sugar after breakfast which is not exceeded throughout the day.

* Fasting.

able blood sugar level will be proportionately increased. When this optimum glucose percentage in the blood is reduced by dietary restrictions, the organism tends to respond by a hyperglycemia on the least provocation. It is under such circumstances that there occurs an increase in the glucose of the blood after the ingestion of protein and fat. Such reactions may go very far to explain the very wide variations in blood sugar often found in cases of diabetes. ${ }^{8}$

8. Mosentha1, H. O., and Lewis, D. S.: Bull. Johns Hopkins Hosp., 1917, . 28, 187. 
It has been shown previously by von Moraczewski ${ }^{9}$ that the blood sugar rises after exercise, and that, in spite of this hyperglycemia, the tolerance for sugar is greater after muscular effort than during rest, when the blood sugar is lower. This holds true, apparently, for the diabetic as well as for the normal individual. Tests of the concentration of the blood in these experiments showed that there was no diminution in the hydremia through sweating, which might have been responsible for an apparent increase in the percentage value of the blood sugar. Thus, it seems that the human organism is able to utilize glucose more effectively when the blood sugar is at a high level than at a low one. This is frequently observed clinically and brings up the much debated question whether it is wise to attempt to reduce the blood sugar in every case of diabetes mellitus to a normal level. From the facts given here it would appear that there are some arguments in favor of not carrying such an endeavor too far.

\begin{tabular}{|c|c|c|c|c|c|c|c|}
\hline \multirow{3}{*}{$\begin{array}{c}\text { Summary } \\
\text { of } \\
\text { Table }\end{array}$} & \multicolumn{7}{|c|}{ Blood Sugar per Cent. } \\
\hline & \multirow{2}{*}{ Fusting } & \multicolumn{2}{|c|}{ After Breakfast } & \multicolumn{2}{|c|}{ After Lunch } & \multicolumn{2}{|c|}{ After Supper } \\
\hline & & Maximal & Minimal & Maximal & Minimal & Maximal & Minimal \\
\hline 9 & 0.18 & 0.18 & 0.17 & 0.17 & 0.13 & 0.17 & 0.11 \\
\hline 10 & 0.45 & 0.45 & 0.45 & 0.45 & 0.45 & 0.45 & 0.45 \\
\hline 11 & 0.23 & 0.23 & 0.23 & 0.23 & 0.23 & 0.23 & 0.19 \\
\hline 12 & 0.33 & 0.33 & 0.33 & 0.33 & 0.32 & $\ldots$ & 0.28 \\
\hline 13 & 0.18 & 0.18 & 0.18 & 0.19 & 0.18 & 0.18 & 0.18 \\
\hline 14 & 0.17 & 0.17 & 0.17 & 0.18 & 0.18 & 0.18 & 0.18 \\
\hline 15 & 0.12 & 0.19 & 0.16 & 0.20 & 0.16 & 0.16 & 0.14 \\
\hline 16 & 0.15 & 0.19 & 0.15 & 0.19 & 0.11 & 0.17 & 0.15 \\
\hline 17 & 0.14 & 0.16 & 0.16 & 0.18 & 0.16 & 0.16 & 0.16 \\
\hline 18 & 0.13 & 0.16 & 0.13 & 0.14 & 0.08 & 0.18 & 0.15 \\
\hline 19 & 0.16 & 0.25 & 0.23 & 0.23 & 0.22 & 0.26 & 0.22 \\
\hline 20 & 0.14 & 0.17 & 0.14 & 0.17 & 0.17 & 0.17 & 0.15 \\
\hline
\end{tabular}

Table 21.--Summary from preceding tables. Summary of the hourly determinations of blood sugar in cases of diabetes mellitus on a carbohydrate-free diet, or one containing a moderate amount of starch. If there is a rise of blood sugar in the course of the day, the maximal value reached one or two hours after breakfast is usually not exceeded to any marked degree after lunch or supper. There frequently is a diminution in the glycemia in the afternoon and evening.

9. Von Moraczewski, W.: Berl. klin. Wchnschr., 1915, 52, 1038; ibid., Ztschr. f. biol. Chem., 1915, 71, 268. 


\section{SUMMARY}

The maximal percentage of blood sugar occurring in diabetic individuals on a carbohydrate-free diet, or one containing a moderate amount of starch, can be obtained by making the determinations one to two hours after breakfast. The glycemia may rise somewhat higher after lunch or supper, but never to any marked degree. On the other hand, the blood sugar may fall considerably in the afternoon and evening hours, leading to erroneous interpretations if taken at this time of day (Table 21).

In diabetic cases there is a tendency for the blood sugar to remain constant throughout the day while on a protein-fat diet, if the fasting blood sugar is high; on the other hand, if the fasting blood sugar is low, that is, if it has been reduced by previous dietetic treatment, there is an increase which may become very marked in the glycemia after carbohydrate-free food (Table 21). This leads to the conclusion that cases of diabetes mellitus, in raising their fasting or basal blood sugar percentage, are trying to adjust their carbohydrate metabolism for the more advantageous utilization of glucose. It may be desirable, therefore, not to attempt to reduce the blood sugar to a normal value in cases of diabetes mellitus.

Johns Hopkins Hospital. 